\title{
Dior Product Mix Analysis Research
}

\author{
Zheng Jingjing ${ }^{1}$, Ruan Jinhua ${ }^{1}$, Hu Shouzhong ${ }^{2,}$ * \\ ${ }^{1}$ Fashion Design and Engineering, Shanghai University of Engineering Science, Shanghai, China \\ ${ }^{2}$ College of Fashion, Shanghai University of Engineering Science, Shanghai, China
}

Email address:

hushzh@sues.edu.cn (Hu Shouzhong)

\section{To cite this article:}

Zheng Jingjing, Ruan Jinhua, Hu Shouzhong. Dior Product Mix Analysis Research. Journal of Human Resource Management. Vol. 3, No. 4, 2015, pp. 33-41. doi: 10.11648/j.jhrm.20150304.11

\begin{abstract}
Dior is synonymous with gorgeous and elegant, is the French fashion brand famous, Dior also is the world's largest high fashion brand LVMH Group's parent company, holding company. The French mix of "God" and "gold", then the golden has become the most common Dior brand colors. Since its inception in 1946, Dior inherits the tradition of French haute couture, fine workmanship, represents the high society women mature aesthetic taste, symbolizing the supreme spirit of French fashion culture. Whether women's clothing, men's clothing, jewelry, perfume, cosmetics or other products, Kristen Dior has been ranked top in the fashion house. With the rapid development of economy, people life rhythm accelerate, fast fashion has become the theme we pursue the trend of Fashion, so many famous clothing brands continue to accelerate the pace of innovation, shorter product life cycle, expand product width and depth. For example, Chanel. GUCCI. Hermes and so on. Today, the Dior brand range also to try, continuous innovation, continuous development. In the expansion of product domain at the same time, Dior can always maintain its elegant style and taste. Dior as the main force in the halls of fashion, the width and depth of its product portfolio is the most. Analysis of the investigation will start to come from a mysterious Dior Europe, product status and development trend of the combination of Dior depth analysis.
\end{abstract}

Keywords: Product Mix, Dior, Latest Fashion, Garment Accessories, Makeup

\section{Product Portfolio}

\subsection{Definition}

Varieties of all kinds product portfolio, which is also called "product collection (the product assortment)", refers to an enterprise in a certain period of production and operation of various products of all products, product project combination. Product portfolio including product project, that is, product categories in different varieties, specifications, quality of a specific product, product catalog listed in each specific varieties is product of a project, including product line. Product line is a collection of many products, these products are composed of a product line, because these products have similar function, user is the same, the same distribution channels, consumer are jointly and severally, etc. A good portfolio of products generally meet the following three criteria:

1) is not profit but have good development prospects, expected to become the future main products of new products;

2) has reached the high profit margins, the highest growth rate and high share of main products;
3) although there are still higher profit margins and sales growth rate has trended to reduce the maintenance of the product .And have decided to eliminate, gradually shrink its investment to reduce the loss to the enterprise recession products.

\subsection{Strategy and Type}

Enterprise is analyzed from the aspects of product line, in view of the change trend of the market, adjust the structure of existing products, so as to seek and maintain product structure optimization, this is product portfolio strategy. Product portfolio strategy include: expanding the product portfolio strategy, to reduce the product portfolio strategy, a high grade product, cheap products.

\subsubsection{Expand the Product Portfolio Strategy}

It is to develop product portfolio of the breadth and the depth of the portfolio. Develop product portfolio breadth refers to add one or several production lines, extend product scope of business; Its product portfolio is to point to in the original product line increase in new product project. The specific methods are as follows: 
(1) in the premise of maintaining the original quality and price, increase the specification, type and style of the same product.

(2) By increasing the different quality and price of the same kind of product.

(3) By increasing the similar product as the original ones.

(4) By increasing something that had nothing to do with the original product.

Enterprises through the advantage to expand product portfolio strategy as follows:

(1) Different preferences of consumers to meet the multifaceted needs, improve the product's market share.

(2) make full use of corporate reputation and brand awareness, improve product series, expand the scale of operation.

(3) make full use of enterprise resources and surplus production capacity, improve the economic benefit.

(4) reduce the influence of market volatility, market risk, reduce loss rate.

\subsubsection{Cut Combination}

Reduce product portfolio strategy is to cut product lines or product project, especially to cancel those small profit products, in order to concentrate on operating profit product lines and product items. Cut the combination way of products are:

(1) reduce the number of product lines, production and marketing of professional.

(2) to keep the original product line cut product project, certain products to stop production, outsourcing products continue to sell.

The advantage of reduced portfolio are:

(1) concentration of resources and technology improvement to keep product quality, improve product brand visibility.

(2) specialized in production and management, improve the production efficiency, reduce production costs.

(3) it is helpful for the further development of the enterprise to market, to seek the right target market.

(4) reduce capital takes up, accelerate the capital turnover.

\subsubsection{High Grade Products}

High-end product strategy, that is, in the original product line increase in high grade, the high price of product. A highend product strategy mainly has some benefits like this:

(1) The production and operation of high-grade products easy to bring huge profits for the enterprise.

(2) improve the enterprise prestige existing products, and improve the product's market position.

(3) drive the enterprise production technology and the improvement of management level.

\subsubsection{Low Grade Products}

Cheap product strategy, increase in the original product line is a project of low grade, low price products. The benefits of a low-grade product strategy is:

(1) borrow the reputation of the high-end brand products, attracting admiring the low level of consumption of customers to buy cheap cheaper products in the product line.

(2) make full use of existing enterprise production capacity, supply product project, blank forming products.

(3) increase sales and expand market share.

With a high grade product strategy, the practice of lowgrade product strategy can rapidly for enterprises to seek new market opportunities, and at the same time also can bring certain risks. If mishandled, could affect the enterprise original products market reputation and market image of the brand products. In addition, the implementation of the strategy needs to have a set of the corresponding system of marketing and promotion and cooperation, which will inevitably increase the cost of enterprise marketing spending.

\subsection{Four Key Factors}

Product portfolio includes four factors: product series, length, the width of the depth of the products and product series. These four factors, constitutes a different product portfolio.

\subsubsection{The Width}

Refers to the total number of enterprise product line. Product line, also known as product categories, product series, refers to a group of closely related product items. Here is closely related to the can be use the same production technology. products have similar functions, the same kind of customers, or are of a price range. For a home appliance production enterprises, can have a TV production line, refrigerator production line. The width of the product portfolio shows the business scope of the enterprise size, cross-industry business, even the degree of diversification management. Increase the width of the product portfolio, can give full play to the specialty of the enterprise, making the full use of the resources of the enterprise, improving the management benefit. In addition, the risk can be reduced by diversification management.

\subsubsection{The Length}

It refers to the total number of the product of an enterprise project. Product project refers to the listed in the enterprise product line with different specification, type, style or price is the most basic unit of product. Usually, each product line includes multiple production projects, project total number of each product line product is enterprise product portfolio length.

\subsubsection{The Depth}

The depth of the product portfolio is refers to the product line in each product how many varieties. Offline suppose Dior perfume products project there are $\mathrm{n}, \mathrm{m}$ is one of them, there are three kinds of specifications and $\mathrm{m}$ perfume and two kinds of formula, so the depth of the $m$ of Dior perfume is $\mathrm{nm}$. Product portfolio reflects the length and depth of the enterprises meet various small molecule market levels. Increasing product project, product specification, type, style, design and color caters to different market segments different needs and interests of consumers, attract, and attract more customers. 


\subsubsection{The Correlation}

Refers to an enterprise's each product line in the end use, production conditions, the associated degree of distribution channels, etc. Higher performance products associated enterprises of scale and scope of benefit, improve the enterprise in a certain region, the reputation of the industry.

\section{Dior}

Dior has a long history of clothing brand, its product portfolio strategy use also relatively well and the benefits of the growing.

\subsection{Brand Introduction}

Christian Dior in 1905 was born in Normandy, France "Dior" in the article is "god" and the combination of "gold" (or), later became a golden Dior brand of the most common color. Christian Dior is not garment design, graduated from the Paris institute of political, and as a son of the entrepreneur, his passion for the arts never faded. In 1946, after the fashion constantly fugitive dust, has 40 from Christian Dior to Montaigne avenue in Paris opened the first personal clothing stores. Dior is the world famous brand of fashion consumption. Mainly Dior is engaged in women's, men's clothing, jewelry, perfume, cosmetics and other highend consumer goods.

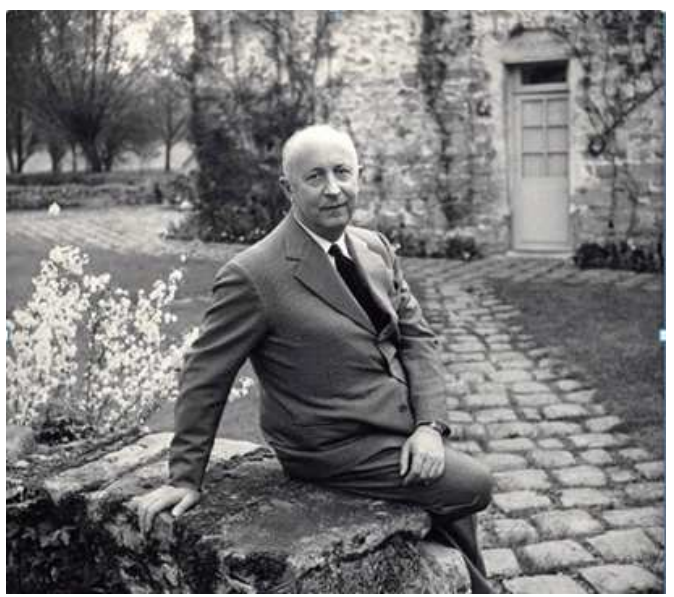

Figure 1. Christian Dior.

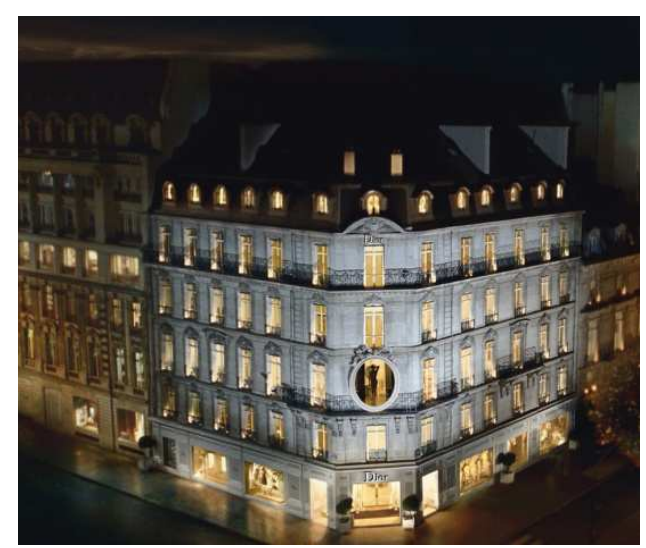

Figure 2. Dior Paris head office building.

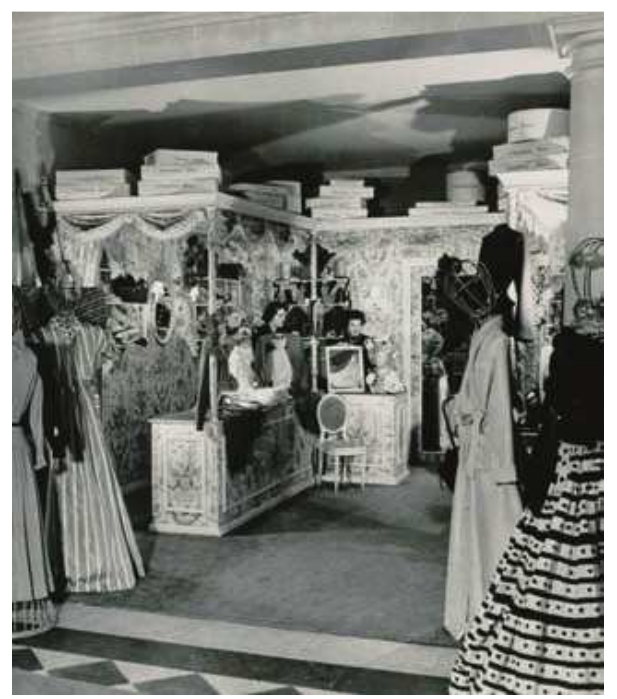

Figure 3. the first Christian Dior.

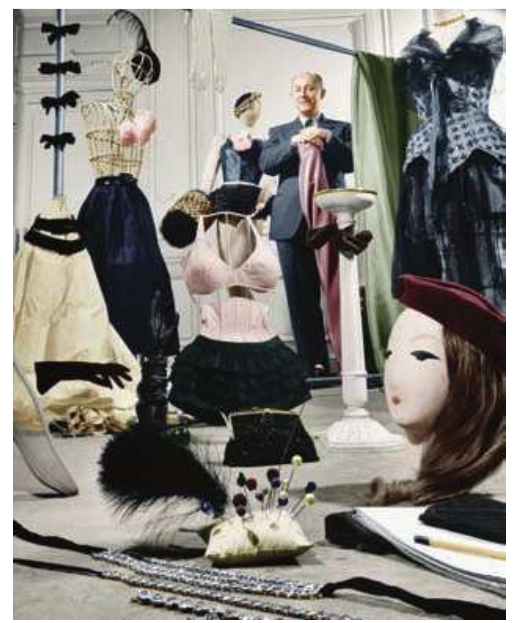

Figure 4. Mr. Dior between the four women's clothing accessories.

Look up to and look forward to the top of the fashion pyramid, decades or even hundreds of years of small workshop, persistence is a success. Looking back, the land of thorns, this is many international big twists and turns of life. Louis Vuitton, a disciple trapped, but due to observe details to create the legend brand family: Anna Sui. College dropout in an apartment to buy a sewing machine, began to arrives the world. Ferragam o, went to the United States, to move around the end of becoming a movie star special shoemaker, after the Wall Street crash, after the collapse of a back come.

Dior is through the darkness, and ultimately become the French haute couture highest symbol, looking back footprint, perhaps more thorns...

Early in 1935, Christine was independent. Dior has experienced a very dark time. Every day he had to search jobs from the small ads in the newspaper, he has no fixed address, sometimes with friends, and sometimes to sleep on the street, hungry meal, full meal, eventually had tuberculosis. Nevertheless, Christian Dior is not down. One day when Christian Dior for couldn't find a job in a deep disappointment, a friend of the fashion industry suggested that he did some fashion design, and very popular. Every 
design fully reveals his unique talent, he held on to the dynamic life, every design so lifelike. On February 12, 1947, it was a brilliant day, Dior launched his first senior fashion show, the first fashion series called "New style", New Look, New Look sensation in Paris and even the entire western world, give a person leave deep impression, make the Dior reputation in the fashion industry. Dior Paris during the Second World War not only brought back to the position of fashion center, also hand planted two well-known design master: Pierre Cardin, Yves Saint Laurent (YSL).

\subsection{Scope of Business}

\subsubsection{Fashion}

\section{(i). Haute Couture}

Enlighten abstruse design, the emphasis is on the female model lines of clothing rather than color, emphasize women convex concave, Gently beautiful curve, Dior dress form in the design of Dior women unique charm is incisively and vividly reflected, in this bold fully embodies the central plains will not be appreciated by Dior black hand is also a popular color, the design of the Dior swept away women's conservative and inflexible line after world war ii, the design of France and the western world of sensation, let a female. For the Dior fashion and luxuriant, late outfit, luxury, luxury, in legends and creativity, classical and modern, hale and hearty and tenderness to seek unity of evening dress always let people breath, startled.

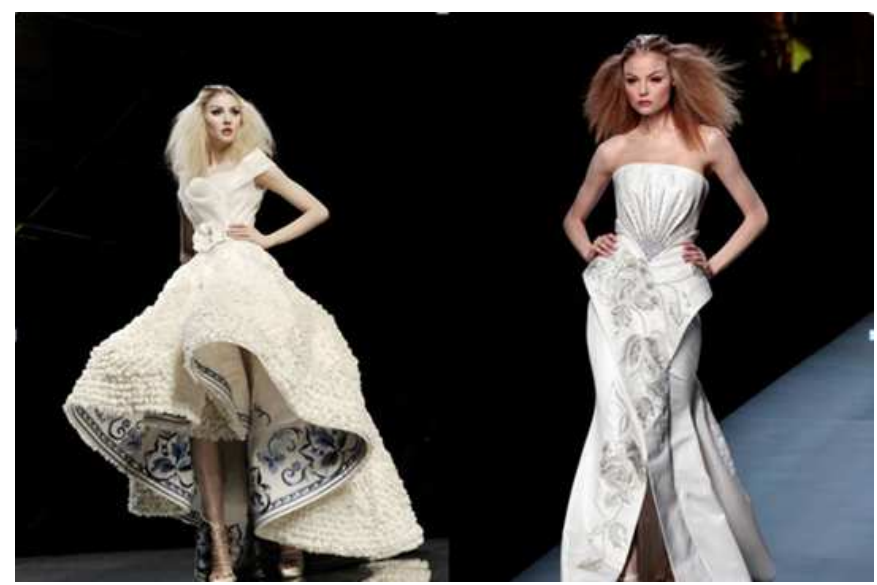

Figure 5. haute couture

\section{(ii). Couture}

Genius master design was adopted for the Dior multilevel model, free collocation with fur, the elegant narrow skirt, pants, has never been able to make the wearer walk freely, embodies the perfect combination of elegance and practical. Dior's revolutionary also working to fashion comprehensibility; Choosing good fabrics such as silk, traditional cloth, wool, taffeta, luxuriant embroidery, etc. The more advanced in fine craftsmanship. In the process of postwar reconstruction of Paris world fashion center, Dior has made an indelible contribution.

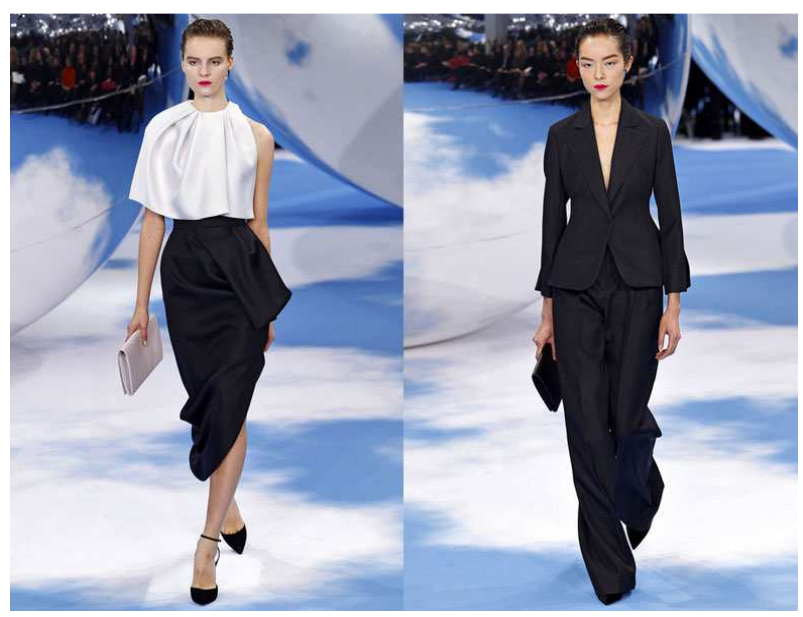

Figure 6. Dior couture.

\section{(iii). Dior Homme}

Dior Homme Christian Dior's men's wear brand, developed in July 2000, then the whole reached its peak of the vehemence of the men's wear brand. Yves saint Laurent YSL designers before Hedi Slimane since the 2001/02 season started as Dior men's chief designer. Seeley, thin body of men's clothing, his design is tightly closed type more, there is no lack of some of the rock and roll style.

Hedi Slimane not only love rock, also obsessed with photography, open the exhibition many times, he biggest wish is to become a reporter, but never wanted to be a dress designer, he started studying the classical literature, then switched to political science and the study of art history, he is from 1989 to 1995, Mr. Levy and Jean - Jacques Picart assistant, talented high-profile, in several different projects including Louis Vuitton Monogram service of one hundred memorial project advisers to the clothing, in July 1997, Hedi Slimane was appointed to the left bank of Yves Saint Laurent menswear (Rive Gauche Homme) of the art director, published in the 2000/2001 year autumn and winter 's "Black Tie" series, he stepped back and join the Dior, as men's creative director, is responsible for the full range and global image.

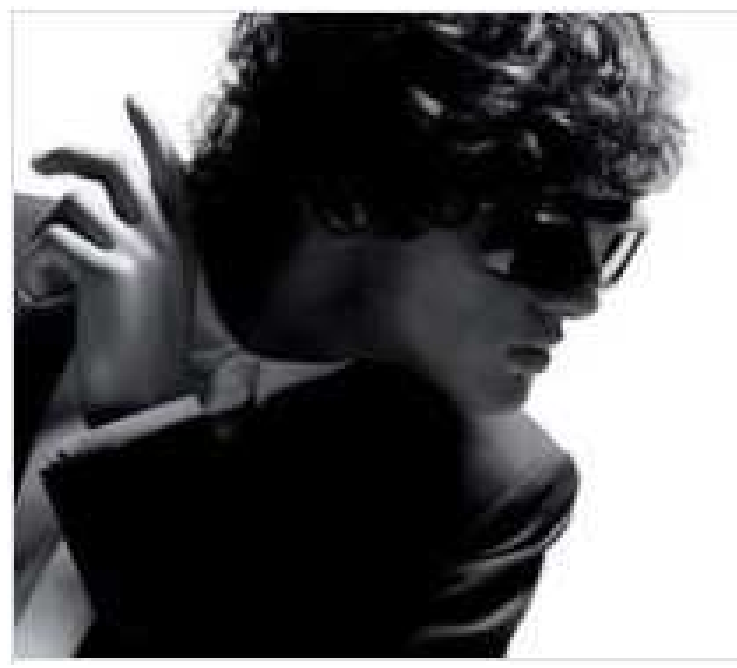

Figure 7. Mr.Hedi Slimane. 
This paper choose the Dior Dior Homme Paris 2014 spring and summer series of men's do men's clothing style show. Maze consisting of a mirror covered at this season of clothing from the shirt, vest to shorts, windbreaker, deep blue and wine red two color the game. Delicate three-piece suit or vest combined with the suit bunt, again with wine red or navy blue mix build, cutting material and the originality of design, make the Dior Homme get interesting.

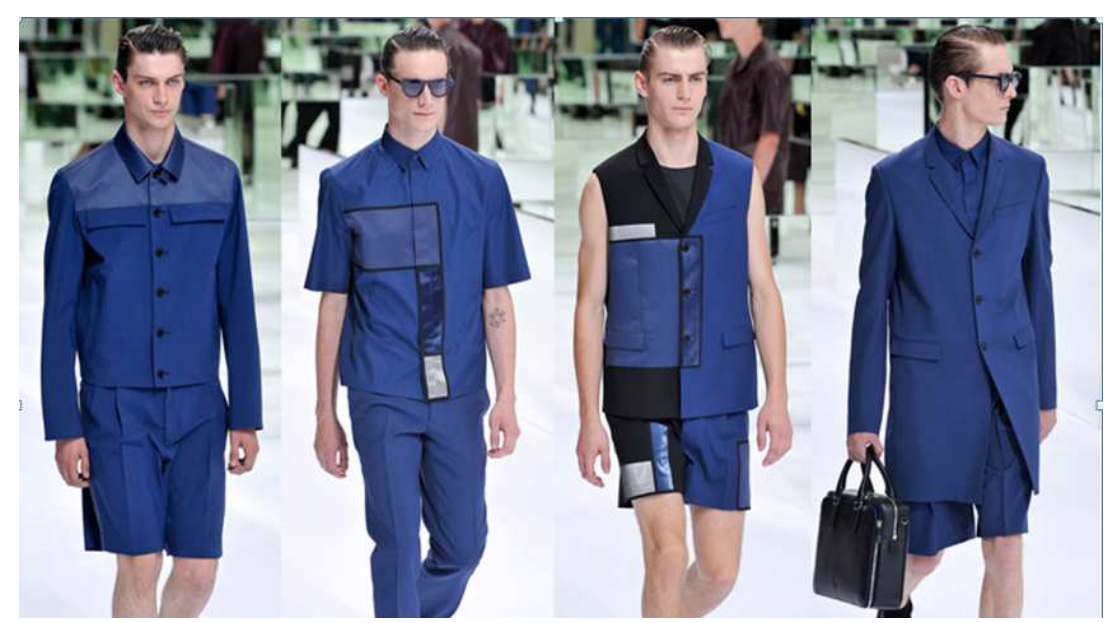

Figure 8. dark blue.

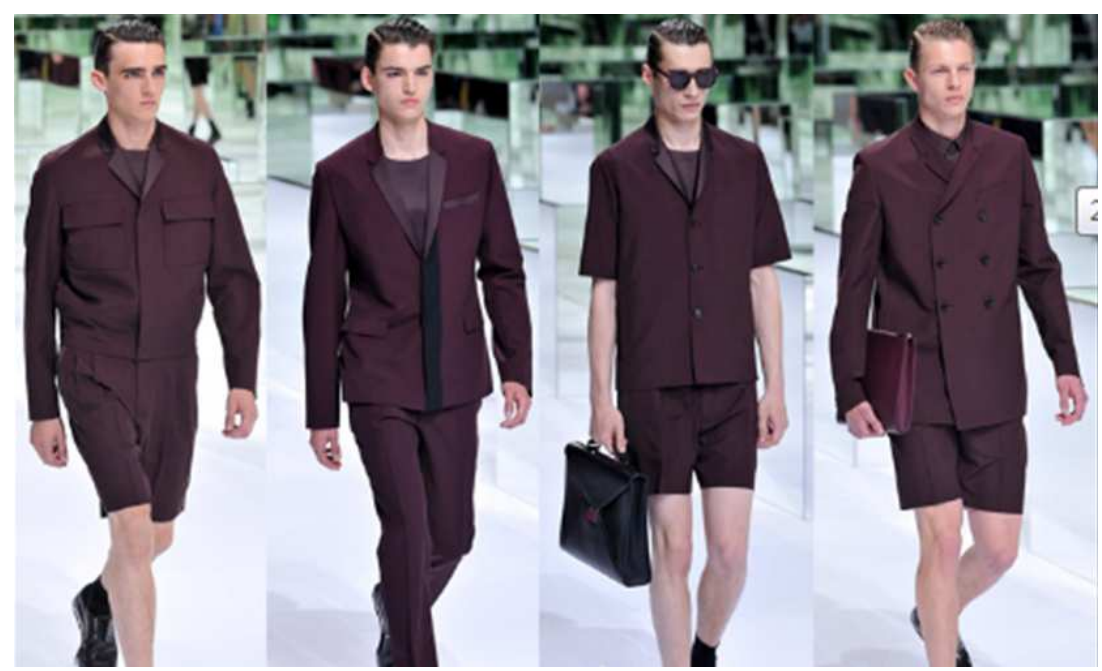

Figure 9. wine red.

\subsubsection{Accessories}

\section{(i). Jewelry}

Dior jewelry gorgeous feelings are fantastic to the world. Dior jewelry widely draws inspiration from various historical style, never simply copy some kind of appearance, but through the colorful gems work novel character, creating unique jewelry design. In 1995, Dior has developed much money together with Swarovski aurora borealis rhinestone, greatly enriched the jewelry made of color and texture. In addition, Dior jewelry is another feature of bold use flower pattern, it also reflects the founder Mr. Dior for the love of nature. Not well-known small wildflowers, strong love roses, are obvious design theme, and the valley of pure lily to be the classic design of the Dior jewelry brand.
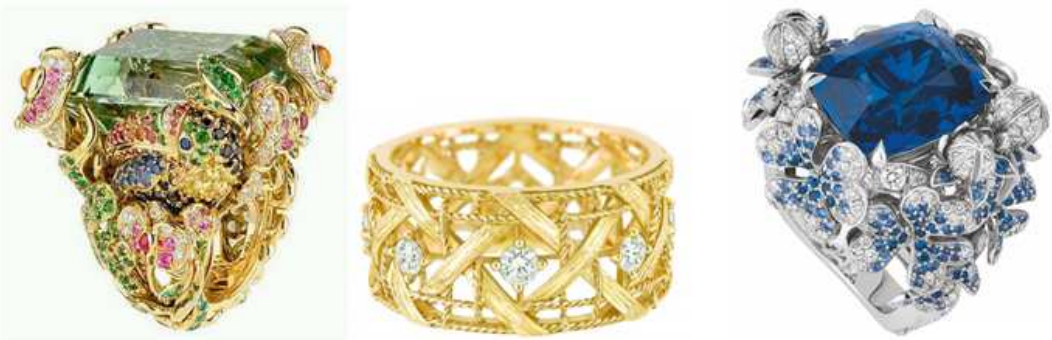

Figure 10. Dior luxury diamond ring. 

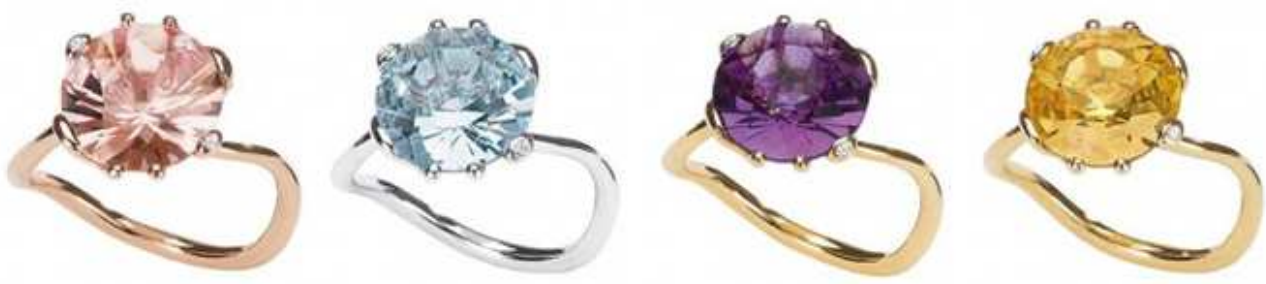

Figure 11. Dior elegant diamond ring four color series.
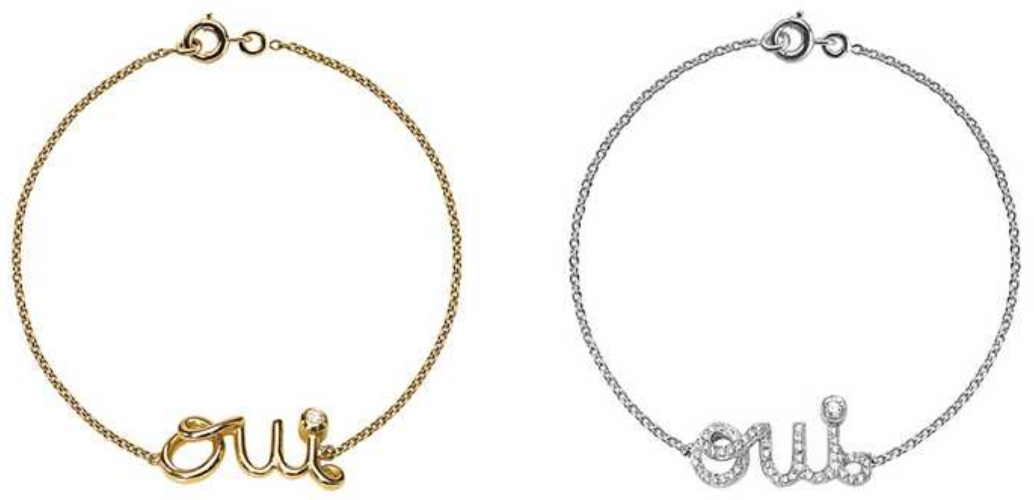

Figure 12. Dior gold, silver color bracelet series.

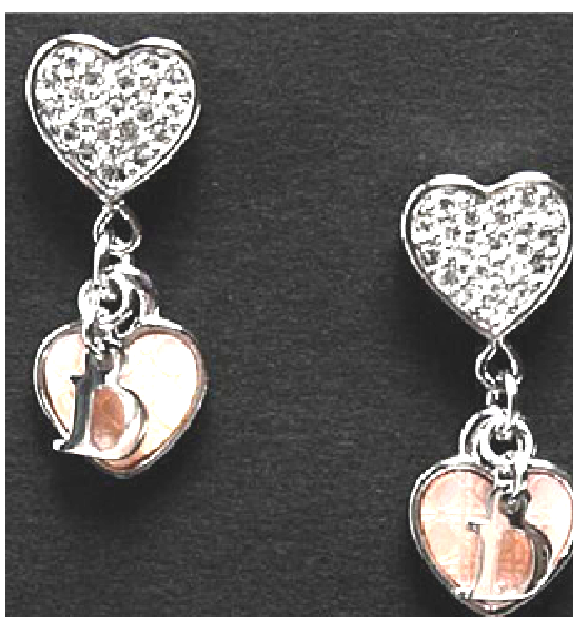

Figure 13. Dior eardrop.

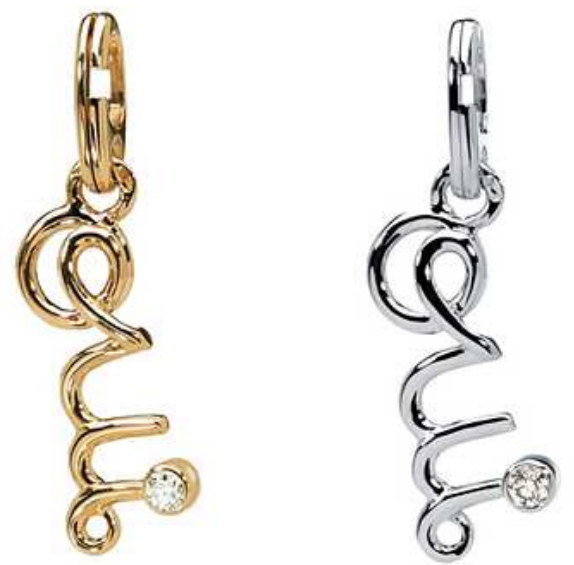

Figure 14. Dior's accessories.

\section{(ii). Watches}

Since the late 1970 s, Dior gradually began to watch the manufacturing sector, but in the initial period of time, Dior watches ideas have been stick to traditional watches model design, did not use real popular Dior's own style. In 2000, the designer John Galliano started capturing the Dior. Dior watch works hard to give a person with surprise, it is hard to get rid of the shackles of fashion brands. After entering the new century, and gradually began to change direction, Dior watch can strive to become a professional business.

Following the Dior crystal diamond Rubber sheet series since the spring of 2008 has launched the most impressive after hooking up red with classic charm blue, 2009 new Purple crystal Rubber watch money also. When the rubber band is endowed with the vitality of purple luxury, the superego personality in an instant comes into the bottom of my heart. Both in the movement of passion, hot and in luxurious party, it is the envy of dizzy.
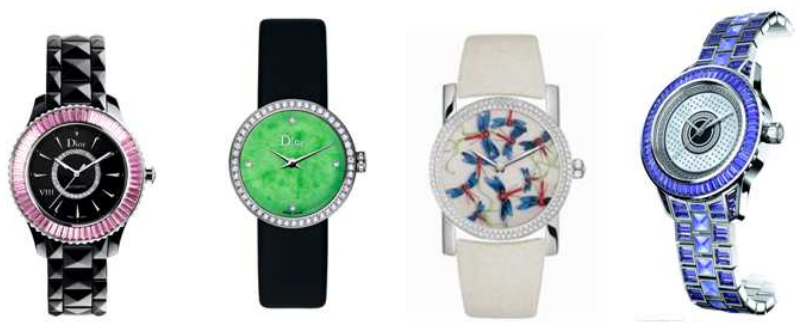

Figure 15. Dior watches.

\section{(iii). Glasses}

Dior glasses style of elaborate carve on the details, innovative technology and excellent on the line, outline a clear see. Beside the elegant logo, glasses itself in outline, and avant-garde design and color to attract the public eye. On 
each Dior frames or sunglass with Dior, obviously shown the wearer's taste and identity. Younger picture frame, design into fashion sexy fluent line, have a new feeling. Counting classic trend, Dior glasses are always important, thin and light frame, streamlined design, more foil wear the eyes of people.
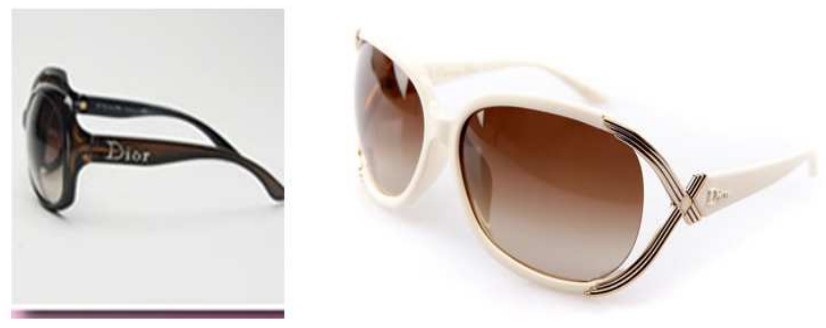

Figure 16. Dior glasses.

\section{(iv). Women's Shoes}

Dior shoes carefully, bold, innovative design, each reflects the sexy and elegant, so that the Women cannot help buying them.

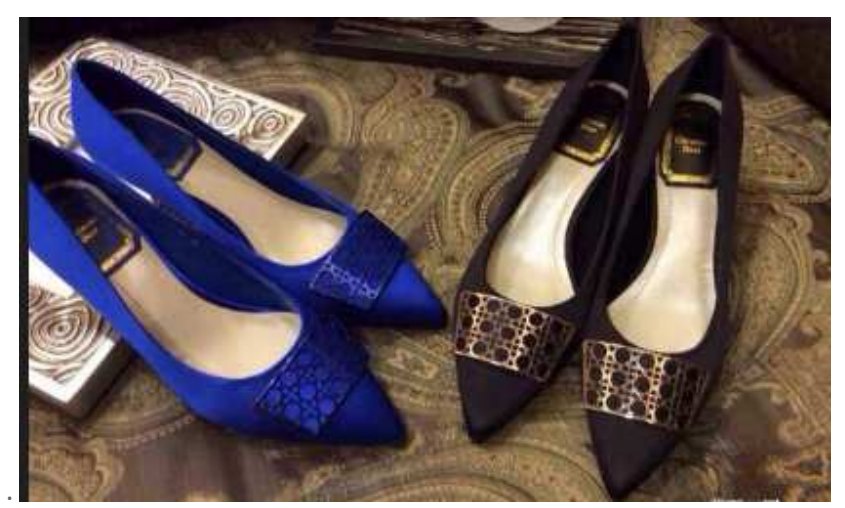

\subsubsection{Make-up}

Dior cosmetics including skincare, make-up, perfume, nail oil, as well as men to protect skin to taste, the following is a detailed introduction:

\section{(i). Skin Care}

Facial essence prevent bask in segregation frost/other maintenance/eye essence facial scrub/purchase Dior chamfer makeup mask/toner/water spray cleansing lotion/cream/activity to repair essence dew

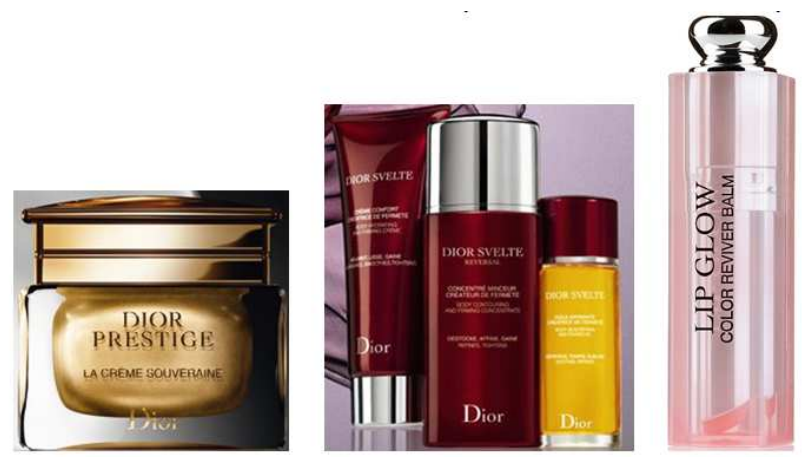

Figure 18. Dior cosmetics.

\section{(ii). Color Makeup}

Highlights/shadow pink lip pen/pencil eyebrow pencil eyebrow powder bread/eyebrow eyeliner/liquid eyeliner/eyeliner/rouge powdery cake skin/lip honey lip balm/mouth red makeup before bottom liquid/powder foundation cream /foundation cream eyelash to cream eye shadow powder/ beauty tools/other color makeup powder

Figure 17. Dior Women's shoes.
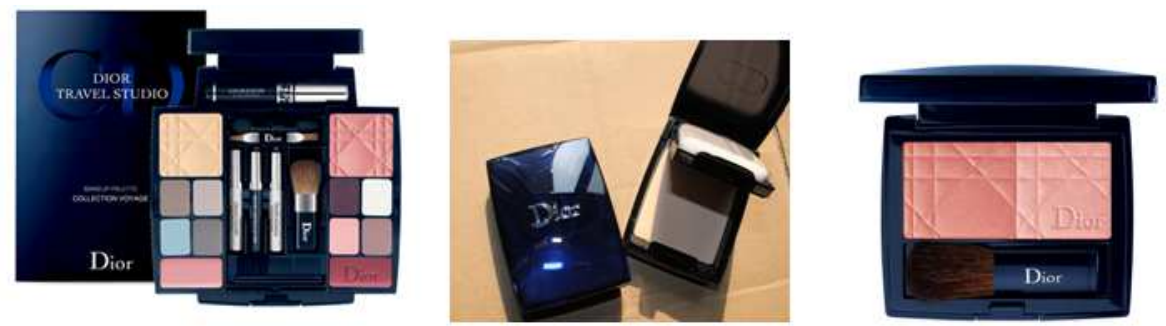

Figure 19. Dior eye shadow, powdery cake, cheek is red.
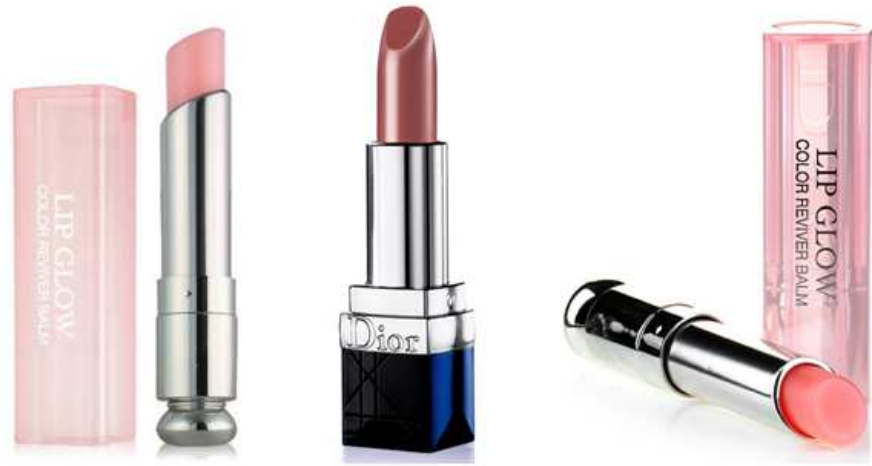

Figure 20. Dior Lip gloss. 


\section{(iii). Perfume}

Christian Dior fashion shop is established in 1947, the same year, Christian Dior founded the Perfumes Christian Dior, launching new called Miss Dior perfume, is a kind of green plant chypre. Dior perfume dream no matter from
"Miss Dior" to "Dior Addict" of Dior perfume, allencompassing, into the dream. Christian Dior perfume can cater to all kinds of women, men and different emotions. The perfumes the unexpected allure is impossible to resist, also is the art of perfume manufacturing tycoons
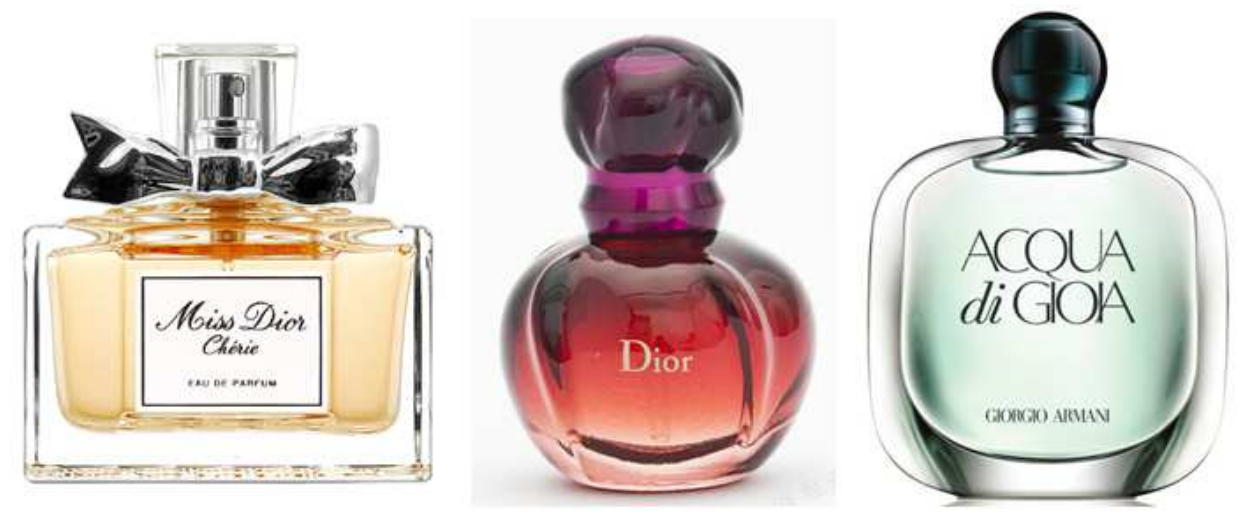

Figure 21. Dior perfume series.

\section{(iv). Nail}

Nursing nail polish Color nail polish

\subsubsection{Bags}

Dior bags give a person a kind of avant-courier, atmosphere of visual art to enjoy. Its classical style, new process makes Dior handbags many colors and fabrics bag lovers must perfect item. Beautiful colors and concise beautiful fashionable bag or joker contracted. Also use hollow out the cane makes up, quilts, handmade beaded hair, such as process design of classic Lady Dior handbag can bring forward more pioneer art of visual enjoyment.
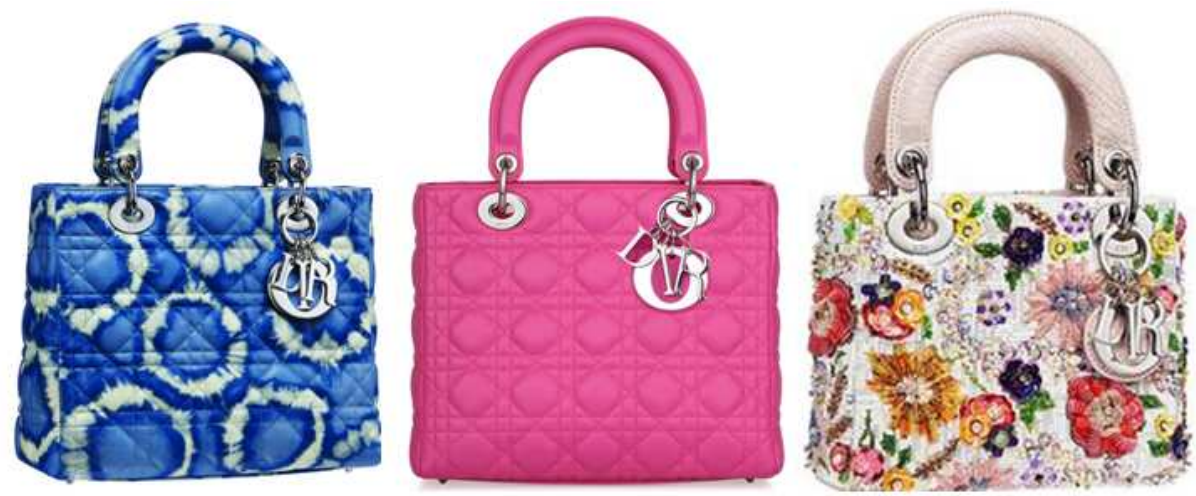

Figure 22. Dior female package series.

\section{Analysis}

\subsection{The Project Design}

1) to investigate location: Nanjing west road hang lung plaza

2) investigation of time: on November 8, 2014 on Saturday afternoon

3) use tools: camera, pen, notebook

4) subjects: hang lung plaza, Dior flagship store on the second floor

5) investigation tasks:

(1) understanding the approximate location of a Dior flagship store and the geographical advantage.
(2) the panoramic camera store appearance.

(3) into the shop to observe Dior store decoration design and structure.

(4) look at Dior product variety and combinations.

(5) Pictures were taken of the product.

(6) The seller consultation product portfolio and product sales and other related issues, collect the necessary data.

\subsection{Problems and Solutions}

\subsubsection{Problems}

1. Dior as a world famous brand, although the advantage in information technology, but because of its enormous business development, which may lead to some areas of control is not strong, resulting in the partial loss of profits. 
2. Dior production in the form of products, continue to expand product portfolio, length, width, depth, etc., in the long term may be on the adaptability than focus more on competition exists in the field of a disadvantage.

3. the globalization currently only opens up a few dozens of national market, there are still loopholes in the market.

4. Dior stores in Shanghai, only two, one is hang lung plaza, another is the IFC. It is not enough for an international metropolis, be badly in need of open shops.

5. hang lung plaza entrance, no Dior metope of propaganda, on the contrary in the roof, opposite the entrance was set up with Dior, this design is not obvious, should be properly adjusted.

6. Dior store seller too much, will cause customer shopping a sense of urgency, let the customer can't easy shopping.

7. Dior store all kinds of product placement more casual, correlation is not strong.

\subsubsection{Solutions}

1. To strengthen the weak link of control, absorb excellent management personnel, in charge of the various product module, avoid the excessive expansion of product lines to ignore enhance advantages brought about by the disadvantages.

2. market development scope should continue to expand.

3. increase the stores in Shanghai, to meet consumer demand at the same time increase benefits.

4. the publicity board position changes, let consumer can easily see the sign.

5. a reduction in the number of assistants, play some soothing music, with some coffee.

6 . the product put design to be more artistic, relevance.

\subsection{Summary and Market Forecast}

DIOR is very good at using the opportunity to brand as the intangible assets, involving various clothing category, with unknown to store, in part of China's high-end goods are sold, DIOR dress designing thought and theory of different, only on a standard scale of CHRISTIAN DIOR, contains a second line at home and abroad well-known clothing franchise brand of high-grade brand products, integrating the thousands of clothing enterprises at home and abroad of unwanted inventory, orders the tail goods, large single procurement, no matter from quality, from the commodity price is the maximum to meet customer demand.

At present, of the risk of Dior star endorsement events, Dior, please Mr. Sharon stone endorsement expensive risk is big, the celebrity strategy also has many risks, such as the choice of celebrity scandals, but may be out of favour, overnight corporate image rather than ascension and to take all of a sudden crisis management.

\section{Acknowledgement}

The study was conducted by the Shanghai science and technology commission (13 dz2294300) public service platform project, Shanghai municipal education commission funded scientific research innovation projects (13 zs173).

\section{References}

[1] Wu Fong Gong. Effects of color display, color name, color formation and color alignment on the screen layout usability of customized product color combinations.

[2] Zhang Peng. The combinations of Clothing brand series products. Academic BBS 2012.9.

[3] Meng Jin. Based on the correlation method of clothing brand portfolio research. Journal of Zhejiang textile vocational technology college. 2012.12.

[4] Zhou Jing, Hu Sheng Lu. Improved compound algorithm in the application of the product mix optimization. with modern computer. 2009.02.

[5] Liu. Xiao Hong Based on the strategy of product combination fashion quarter order structure health and application of the model. Journal of Zhe Jiang university of science and technology 2014.10.

[6] Zheng Chun Ling leisure brand apparel commodity combination research of the masses[D]. Zhe Jiang university of science and technology, 2010.9.

[7] Zheng Yan Hong. Brand sweater product mix optimization of exploration and application [D]. Zhe jiang university of science and technology, 2010.

[8] Xue Lu Tian Jin University of Technology. Theory of apparel commodity price strategy[J].2009

[9] Li Ya Nan Brand clothing collection store product combination method study. Zhejiang University of Technology Institute of Fashion Technology. 2013. 